\title{
Genetic diversity in European pollen beetle, Meligethes aeneus (Coleoptera: Nitidulidae), populations assessed using AFLP analysis
}

\author{
NADIYA KAZACHKOVA ${ }^{1}$, JOHAN MEIJER ${ }^{1 *}$ and BARBARA EKBOM ${ }^{2}$ \\ ${ }^{1}$ Department of Plant Biology and Forest Genetics, Genetics Center, PO Box 7080, Swedish University of Agricultural Sciences, \\ SE-750 07 Uppsala, Sweden; e-mail: Johan.Meijer@vbsg.slu.se \\ ${ }^{2}$ Department of Ecology, PO Box 7044, Swedish University of Agricultural Sciences, \\ SE-750 07 Uppsala, Sweden
}

Key words. Nitidulidae, AFLP, genetic variation, Meligethes aeneus, genotyping, insecticide resistance, population structure

\begin{abstract}
The pollen beetle (Meligethes aeneus) is one of the most important insect pests of oilseed rape (Brassica napus), and extensive use of insecticides is required to protect crop yields. To meet the challenges set by agricultural demands for more sustainable production and changing climate more information about pest biology and population genetics is needed. Using genomic Amplified Fragment Length Polymorphism (AFLP) analysis, DNA polymorphism was studied in 14 field populations of pollen beetles, collected during 2004 in six European countries (Denmark, France, Finland, Germany, Sweden, and UK). Using one primer combination 410 polymorphic DNA fragments were obtained based on analysis of single beetles. AFLP profiles were analysed with similarity measures using the Nei and Li coefficient and dendrograms generated. Dendrograms constructed from distance matrices revealed clustering by population origin and assignment analysis generally supported the genotype classification. Principal component analysis of the fourteen groups resulted in wide dispersion but also connections between some groups. Statistical analysis using AMOVA showed that the levels of genetic variation within populations explained most of the variation. Migrant analysis suggested a low level of gene flow between pollen beetle populations at different geographical locations indicating little long range dispersal of pollen beetles. However, a Mantel test found no correlation between genetic and geographical distance. Apparently genetic differentiation among populations has a complex background and may involve factors such as local adaptation and founder effects.
\end{abstract}

\section{INTRODUCTION}

One of the most important insect pests of Brassica oilseed crops in Europe is the pollen beetle, Meligethes aeneus (Fabricius 1775) (Coleoptera: Nitidulidae) (Ekbom, 1995). This beetle is a pest of great economic importance because it destroys flowers and buds thereby reducing seed yields. Pollen beetles are univoltine. Adults overwinter and with increasing temperatures in spring they start feeding on the pollen of various plants. When temperatures rise to $15^{\circ} \mathrm{C}$, adults seek out fields of Brassica oilseed. There they feed on buds and flowers and females lay eggs in flower buds. Larvae remain in the flower bud and feed on pollen. After feeding for 25-30 days the fully-grown larvae drop to the soil where they pupate in earthen cells. Young beetles emerge 2-3 weeks later. A combination of visual, tactile and olfactory cues determines the choice of host plant for oviposition (Ekbom \& Borg, 1996). The myrosinase-glucosinolate defense system of Brassica plants (Rask et al., 2000) is important in these insect interactions. Little information is, however, available about pollen beetle preferences and host plant chemistry. Although pollen beetle incidence on oilseed rape inflorescences is negatively correlated with glucosinolate levels (Giamoustaris \& Mithen, 1996), they do not appear to affect their ovipositing on mustard plants (Hopkins et al., 1998).
Pollen beetles are currently controlled by insecticides and this has a negative impact on non-target organisms including their natural enemies (Nilsson, 2003). In addition, there is a risk that resistance to insecticides will develop, and pyrethroid resistance in pollen beetles has been recently reported from several locations in Europe. It was first recorded in France in 1997 (Détourné et al., 2002) and subsequently in Sweden (Ekbom \& Kuusk, 2001), Denmark (Hansen, 2003), Switzerland (Derron et al., 2004), and Germany (Heimbach et al., 2006). Insecticide resistance, which is the result of an increase in the ability of individuals of an insect species to survive insecticide treatment, is an example of an evolutionary response induced by man (Comins, 1977; ffrenchConstant et al., 2004). Selective forces, genetic variability, gene flow, population size, mating system, migration and life history are typical factors that can interact to change allele frequencies and affect population structure. Interactions between each of these factors will depend on the species considered and environmental conditions. Important components of these interactions are the geographical scale, weather, the extent of the treated areas relative to gene flow, and the cost of resistance for resistant genotypes in the absence of insecticides (Lenormand \& Raymond, 1998). For insect pest species it is important to consider gene flow in the evolution of insecticide resistance and adaptation to local environmental

\footnotetext{
* Correspondig author.
} 
conditions, because a species' pest potential is partially a consequence of its ability to invade and reproduce in novel habitats. Such information helps in determining the spatial scale at which management practices should be implemented (Nahrung \& Allen, 2003). Studies that map the population structure of pest insects as well as the potential for gene flow between populations are needed to understand the occurrence of resistance and prevention of its spread (Roush \& Daly, 1990; Labbe et al., 2005). The dispersal and migratory potential of pollen beetles is poorly studied. Tamir et al. (1967) found that dispersal was not dependent on terrain or current wind directions but their study was limited to a few days. A recent study (Williams et al., 2007) on the anemotactic behaviour of pollen beetles in the field reveals that overwintering and new-generation insects differ in their migratory behaviour. Pollen beetles probably originated from Europe and Asia and are present throughout the Palaearctic region, close to Asia and North Africa (Bonnemaison, 1964).

Genotyping using the PCR-based multilocus DNA fingerprinting technique Amplified Fragment Length Polymorphism (AFLP) analysis was chosen for this study because it detects DNA polymorphisms at specific restriction enzyme sites and provides more information as it detects these polymorphisms at many independent restriction sites simultaneously. Furthermore, AFLP is sensitive and does not depend on any prior knowledge of the genome (Vos et al., 1995). AFLP analysis generates data from a large number of loci, and this is advantageous for studying genetic diversity and population structure (Reineke et al., 1999; Salvato et al., 2002; Campbell et al., 2003; Bensch \& Åkesson, 2005; Blanc et al., 2006). Although a drawback of AFLP is dominance this is partly compensated for by the greater statistical power of the high numbers of polymorphic bi-allelic loci generated (Mariette et al., 2002). We have developed an AFLP protocol for pollen beetles (Kazachkova et al., 2004) that is highly reproducible and generates an appropriate number of DNA fragments for analysis.

The aim of this study was to describe the genetic variation between different populations of European pollen beetles. Populations of pollen beetles from several European countries (Denmark, France, Finland, Germany, Sweden, and UK) were collected and analyzed using AFLP (Kazachkova et al., 2004). We wished to clarify relationships among populations from several geographical areas in order to determine their population structure, whether or not they are genetically distinct, and the level of gene flow between European populations. This is the first investigation of the pollen beetle over a large geographical area and forms the basis for future studies of e.g. insecticide resistance and the effects of different agricultural practices on pollen beetle population structure.

\section{MATERIAL AND METHODS}

\section{Insect material}

Pollen beetles, Meligethes aeneus (Fabricius, 1775) (Coleoptera: Nitidulidae) were collected from six European countries in 2004 (Denmark, France, Finland, Germany, Sweden, and UK); locations and number of samples analyzed are shown in Table 1 . Insects were frozen alive and stored at $-80^{\circ} \mathrm{C}$ or kept in $95 \%$ ethanol (Danish populations) to avoid degradation of DNA. Earlier experiments showed that the quality of pollen beetle DNA for AFLP analysis was not affected by drying, freezing or preservation in ethanol. Ten individuals were chosen randomly from the samples to minimise any differences in sampling bias and relative relatedness among samples. For DNA isolation, a modified cetyltrimethylammonium bromide method (Kazachkova et al., 2004) was used.

\section{Restriction digestion and ligation reactions}

The restriction-ligation step and amplifications as described below were applied using a protocol adopted for analysis of pollen beetles (Kazachkova et al., 2004). Restriction-ligation was performed by mixing $20 \mathrm{ng}$ of template DNA, $10 \times$ ligation buffer, $2 \mathrm{mM}$ ATP, $100 \mathrm{ng} / \mu \mathrm{l} \mathrm{BSA}, 0.05 \mathrm{M} \mathrm{NaCl}, 20$ units Pst $\mathrm{I}$, 50 units EcoRI, 10 units T4DNA ligase, and $5 \mathrm{pM}$ of each double-stranded adapter (EcoRI adaptors EA 1.1, 5'-CTCGTA GACTGCGTACC-3'; EA 1.2, 5'-AATTGGTACGCAGTC-3'; Pst I adaptors PA1.1, 5'-CTCGTAGACTGCGTACATGCA-3'; PA1.2, 5'-TGTACGCAGTCTAC-3'), and incubated for $3 \mathrm{~h}$ at $37^{\circ} \mathrm{C}$.

\section{Amplifications and fragment analysis}

Preamplification reactions contained $0.2 \mathrm{mM}$ dNTPs, 1 unit DNA polymerase DynaZymeII, $10 \times$ buffer, $5 \mathrm{pM}$ of each core primer (PstI, 5'-GACTGCGTACATGCAG-3'; EcoRI, 5'-AGACTGCGTACCAATTC-3') and $4 \mu \mathrm{l}$ of the diluted restricted-ligated DNA in a volume of $20 \mu \mathrm{l}$. The preselective amplification included one cycle for $2 \mathrm{~min}$ at $94^{\circ} \mathrm{C}, 32$ cycles for $30 \mathrm{~s}$ at $94^{\circ} \mathrm{C}, 1 \mathrm{~min}$ at $56^{\circ} \mathrm{C}, 1 \mathrm{~min}$ at $72^{\circ} \mathrm{C}$, and one cycle for $5 \mathrm{~min}$ at $72^{\circ} \mathrm{C}$. Primers and adapters for the AFLP analysis were as described in Vos et al. (1995). The fluorescentlylabelled primers contained extensions of two selective nucleotides (EcoRI, GA; and PstI, AT) at the 3 '-end.

For selective amplification, the same reagents and concentrations as in the preselective step, together with $5 \mathrm{pM}$ of each selective primer and $2.5 \mu \mathrm{l}$ of preamplification product, were used. AFLP reactions were performed for one cycle at $94^{\circ} \mathrm{C}$ for $2 \mathrm{~min}$, then for 11 cycles where the annealing temperature was $65^{\circ} \mathrm{C}$ for the first cycle, and was reduced by $0.7^{\circ} \mathrm{C}$ for each of the ten subsequent cycles. The denaturation and extension steps for each cycle were $94^{\circ} \mathrm{C}$ for $30 \mathrm{~s}$ and $72^{\circ} \mathrm{C}$ for $5 \mathrm{~min}$, respectively. The reaction was followed by 23 cycles for $30 \mathrm{~s}$ at $94^{\circ} \mathrm{C}$, $30 \mathrm{~s}$ at $56^{\circ} \mathrm{C}, 2 \mathrm{~min}$ at $72^{\circ} \mathrm{C}$, and one cycle for $5 \mathrm{~min}$ at $72^{\circ} \mathrm{C}$.

PCR products (mixed with formamide dye and GS-500 LIZ labelled size standard) were size fractionated using a 5\% denaturing polyacrylamide gel. The data were processed using GeneScan analysis software (Perkin Elmer/Applied Biosystems, Foster City, USA) and imported into GenoProfiler version 1.05 (You et al., 2007). Only those peaks that could be unambiguously scored were selected. The threshold level of scaled peak height was set to 100 .

\section{Statistical analyses}

AFLP profiles were converted into a data matrix and analysed by similarity measures using the Nei \& Li coefficient (1979). Similarity measures convert the binary data matrix into a series of distance measures between individuals (Nei \& Li, 1979; Balasaravanan et al., 2003). An unrooted dendrogram was con- 
TABLE 1. Sample information and descriptive statistics for AFLP markers.

\begin{tabular}{lcrrccc}
\hline Samples & Latitude & Longitude & $\mathrm{N}$ & Polymorphic loci (\%) & Expected heterozygosity $(H j)$ & SE $(H j)$ \\
\hline France & & & 27 & 49.0 & 0.126 & 0.008 \\
1 Indre & 46.88 & 2.08 & 9 & 9.0 & 0.033 & 0.006 \\
2 Meurthe et Moselle & 49.00 & 6.00 & 10 & 27.6 & 0.121 & 0.008 \\
3 Seine Maritime & 49.68 & 0.81 & 8 & 33.2 & 0.121 & 0.009 \\
Germany & & & 35 & 62.7 & 0.079 & 0.008 \\
4 Weendelsgraben & 51.567 & 9.850 & 9 & 21.7 & 0.120 & 0.008 \\
5 Rügen & 54.417 & 13.433 & 6 & 30.0 & 0.127 & 0.010 \\
6 Torland & 51.700 & 9.867 & 10 & 39.5 & 0.079 & 0.009 \\
7 Trenthorst & 53.800 & 10.533 & 10 & 23.9 & 0.133 & 0.008 \\
Denmark & & & 28 & 30.0 & 0.027 & 0.009 \\
8 Flakkebjerg & 55.317 & 11.400 & 9 & 7.3 & 0.043 & 0.005 \\
9 Hjørring & 57.433 & 10.533 & 9 & 12.2 & 0.052 & 0.006 \\
10 Holbøh & 54.867 & 9.417 & 10 & 13.9 & 0.082 & 0.007 \\
Sweden & & & 19 & 43.7 & 0.089 & 0.008 \\
11 Högby & 58.333 & 15.100 & 9 & 24.1 & 0.082 & 0.008 \\
12 Svalöv & 55.917 & 13.100 & 10 & 26.1 & 0.060 & 0.008 \\
UK & & & 8 & 17.1 & 0.060 & 0.007 \\
13 Harpenden & 51.800 & -0.350 & 8 & 17.1 & 0.035 & 0.007 \\
Finland & & & 8 & 10.7 & 0.035 & 0.005 \\
14 Lappträsk & 60.633 & 26.217 & 8 & 10.7 & 0.005 \\
\hline N & & & &
\end{tabular}

$\mathrm{N}=$ number of beetles analyzed; $\mathrm{SE}=$ standard error.

structed using the TREECON program (Van de Peer \& De Wachter, 1997) based on the similarity coefficient of Nei \& Li (1979) and the neighbour-joining method of Saitou \& Nei (1987) and confirmed by polymorphism parsimony method using PHYLIP program version 3.63 (Felsenstein, 1989). The bootstrap analysis (Efron et al., 1996) was based on 2,000 permutations. The data were processed statistically by population pairwise $F_{\mathrm{ST}}$ statistics and AMOVA with country as the main group (Labate, 2000; Quinn \& Keough, 2002; Lowe et al., 2004) using Arlequin software (Schneider et al., 2000). The statistical significance of the variance components of the AMOVA and the paired comparisons were determined by nonparametric procedures using 10,000 permutations. The DOH assignment test calculator was used to perform assignment tests (Paetkau et al., 1995), and the average expected heterozygosity and gene diversity (Nei, 1978) for each population was calculated using AFLP-SURV 1.0 software (Vekemans et al., 2002). The correlation between genetic (Nei's genetic distance) and geographic distances was tested with a Mantel test for populations $(9,999$ permutations). A minimum spanning tree was computed from a matrix of pairwise distances calculated between all pairs of haplotypes as described by Rohlf (1973). Principal component analysis (PCA) was performed using a covariance matrix and data standardisation for the different sampling sites with the GenAlEx6 Full Pack Software (Peakall \& Smouse, 2006).

\section{RESULTS}

The AFLP profiles of PCR products of 125 beetles from 14 populations using primer combinations E-GA/P-AT were recorded. Fingerprinting revealed a maximum number of 257 unambiguous polymorphic amplified DNA fragments of up to $700 \mathrm{bp}$ for German populations $(62.7 \%)$ and a minimum of 44 (10.7\%) for the Finnish population (Table 1). Among the populations characterized, Flakkebjerg (Denmark) had the smallest number of polymorphic sites (7.3\% of total) and Torland (Germany) the most (39.5\%). The estimated heterozygosity $(H j)$ ranged from 0.027 in Flakkebjerg to 0.127 in Torland (Table 1).

Gene diversity varied from 0.938 for Finland and the UK to 0.994 for Germany. Patterns differed in the presence or absence of a restriction site (particular band), which enabled the construction of a binary data matrix. There was no support for a correlation between genetic distance and geographic distance (Mantel test: $R=0.125$, $P=0.251)$.

All tree-building methods (Van de Peer \& De Wachter, 1997; Labate, 2000) differentiated most populations, which was also supported by AMOVA analyses. Beetles from the same population almost always clustered together (Fig. 1). Several individuals in the German Torland population did not cluster together but formed several different branches. A few of the German Rügen individuals clustered together with some of the Torland individuals. Bootstrap analysis indicated low support for several branches of the tree but a few, e.g. Högby, were significant (Fig. 1). The Nei similarity coefficient matrix showed the closest correlation (0.957) between the individuals from Lappträsk3 and Lappträsk4 (Finland), whereas Harpenden7 (UK) and Holbøh10 (Denmark) samples were only distantly related (0.067). Minimum spanning tree calculation revealed a minimum connection length between Lappträsk4 and Lappträsk5 samples (4.00 Operational Taxonomic Units (OTU)) and a maximum between Lappträsk1 and Seine Maritime4 (France) (48.00 OTUs). Principal component analysis of the fourteen 


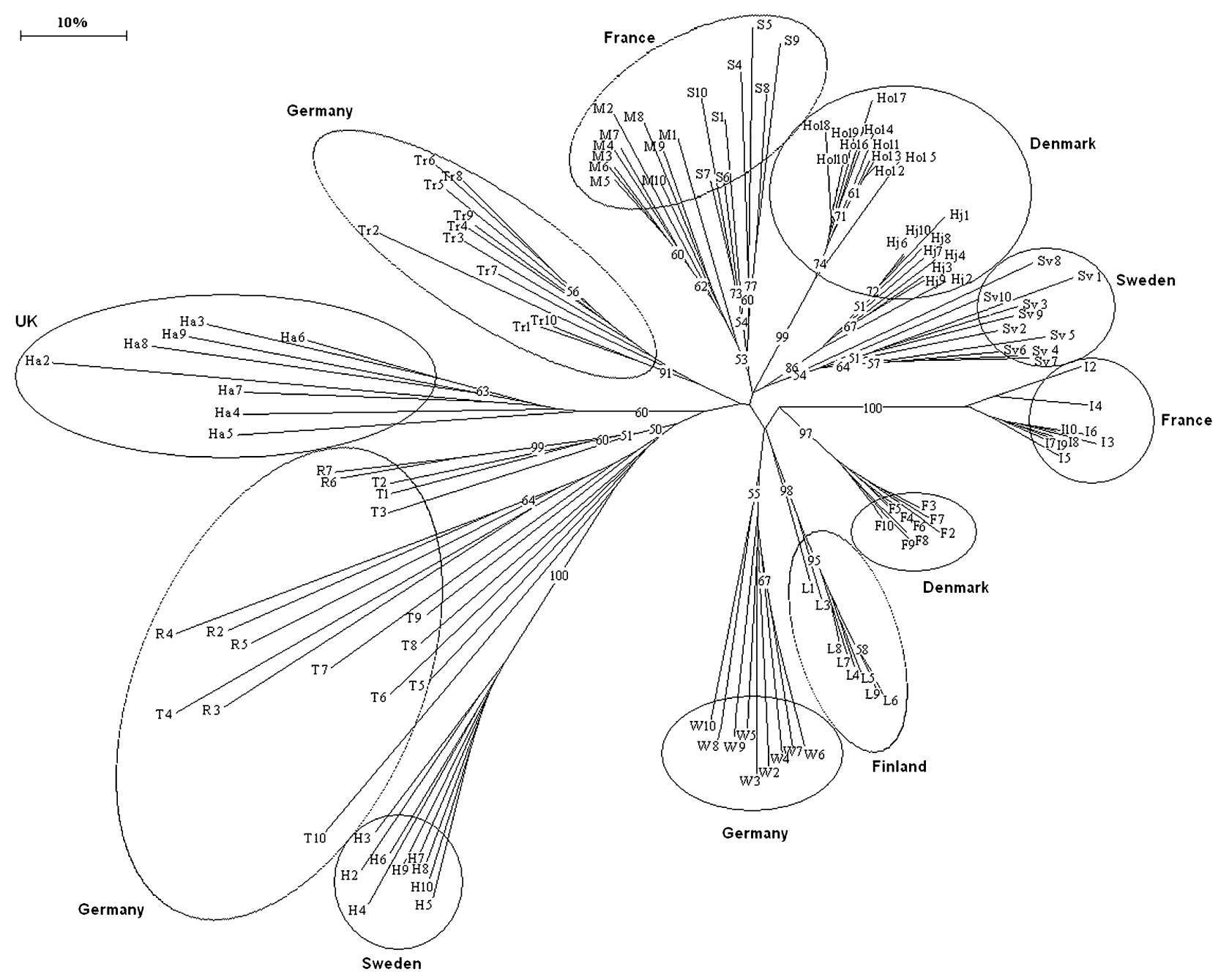

Fig. 1. Dendrogram of European pollen beetle populations based on AFLP analysis. Samples of single pollen beetles from six countries collected during 2004 were analysed using TREECON. The number on the branch represents the bootstrap value based on 2,000 replicates in percent. The dendrogram is based on the analyses of 410 AFLP loci (one primer combination). F - Flakkebjerg; H - Högby; Ha - Harpenden; Hj - Hjørring; Hol - Holbøh; I - Indre; L - Lappträsk; M - Meurthe et Moselle; R - Rügen; S - Seine Maritime; Sv - Svalöv; T - Torland; Tr - Trenthorst; W - Weendelsgraben.

groups resulted in wide dispersion and unexpected connections of some groups (Fig. 2). The first three principle components explained $37.1 \%$ of the variance. Samples from France, UK, Germany, and Finland generally clustered together while those from Sweden and Denmark were more widely dispersed. The position of the sample from Weendelsgraben differed from that of all other groups (Fig. 2).

AMOVA analyses divide variation according to correlations among genotypes rather than variation in gene frequencies. All analysed data were highly significant $(P<$ $0.00001)$. Observed genetic variation within populations $(55.1 \%)$ was significantly higher than the variation observed among countries $(6.3 \%)$ and among populations within countries $(38.5 \%)$ (Table 2). $F_{\text {ST }}$ statistics reflect the departure from random mating caused by population structure relative to the total population due to selection or drift. Population pairwise determinations of $F_{\mathrm{ST}}$ had the lowest value of 0.075 between Rügen and Torland (both Germany). The highest $F_{S T}$ value, 0.705 , was found between the Holbøh (Denmark) and Indre (France) populations. All differentiations between populations were significant (Table 3). Numbers of migrants per generation, $N m=\left(1-F_{S T}\right) / 4 F_{S T}$, were, with only a few exceptions, less than one. When $\mathrm{Nm}<1$ populations are expected to diverge genetically over time, and when $\mathrm{Nm}>1$ populations retain genetic connectivity. Of the 91 pairs of populations, $N m>1$ in 85 of the pairs. The lowest number of migrants per generation was estimated between Holbøh and Indre (0.10) and the highest between Rügen and Torland (3.07). All beetles, with only three exceptions, were assigned to their respective populations. One individual from Lappträsk was assigned to Weendelsgraben, one individual from Rügen was assigned to Torland, and one Torland individual was assigned to Harpenden.

\section{DISCUSSION}

Widespread oilseed Brassica cultivation in Europe has provided an enormous resource for feeding, reproduction and migration of pollen beetles. This study showed a clear genetic divergence among several European popula- 


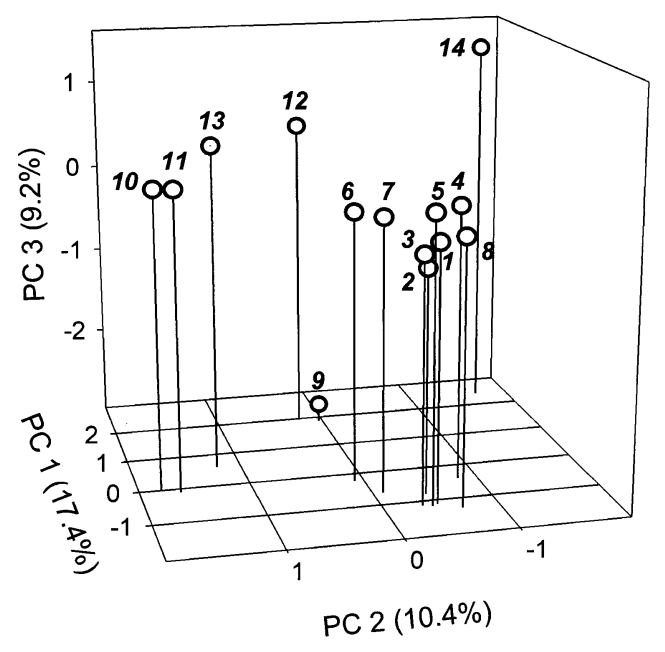

Fig. 2. Principal Component Analysis (PCA) of European pollen beetle populations. The fourteen European samples were analysed using a covariance matrix with data standardization. The first three principle components are shown, the percentages of variation explained are shown on the axes. Locations: 1 Harpenden; 2 - Lappträsk; 3 - Indre; 4 - Meurthe et Moselle; 5 - Rügen; 6 - Seine Maritime; 7 - Torland; 8 - Trenthorst; 9 Weendelsgraben; 10 - Flakkebjerg; 11 - Hjørring; 12 - Holbøh; 13 - Högby; 14 - Svalöv.

tions of pollen beetles as revealed by AFLP markers. The dendrograms constructed from distance matrices showed well-supported branching of several populations but no clear clustering at higher levels. AMOVA supported the clustering analysis by comparatively high genetic variation among populations. Estimates for migration between populations were generally low. This is in contrast to results for Swedish pollen beetle populations (Kazachkova et al., 2007), where, for example, population pairwise determinations of $F_{\text {ST }}$ between Swedish populations were much lower than for the European populations in this study. This may be a result of the different scales of the two pollen beetle studies, sampling, and the fact that the Swedish study had a temporal component. Despite some differentiation found in the dendrogram analysis, the Mantel test revealed no correlation between geographic and genetic distances. When the groups were analysed by principal component analysis the UK sample clustered together with Finnish, French, and German samples while the Swedish and Danish samples were well separated from the other group. Apparently, there is some connectivity in the genotypes that makes it possible to group populations of different origin.
The genetic divergence observed among several European pollen beetle populations is influenced by many factors that promote (natural selection, random genetic drift, and mutations) or delay or prevent differentiation (phenotypic plasticity and gene flow). The high level of genetic divergence observed among many European populations of pollen beetle could be interpreted as a low gene flow. Both intrinsic (i.e., biological; reproductive system and dispersal behaviours) and extrinsic (i.e., environment; physical barriers and selection gradients) are expected to influence gene flow. Thus, gene flow between populations of a species is a complex interaction between the dispersal ability of a species and its physical environment. The geographic differentiation of pollen beetle populations does not seem to be explained by physical separation. The Baltic Sea forms a putative barrier to gene flow between Swedish and Finnish populations, and the North Sea and the English Channel separate the UK from the rest of Europe, but the connectivity based on principal component analysis showed the sample from UK to cluster together with Finnish, French, and German samples. Furthermore the Swedish and Danish samples were partially separated from each and well separated from the main group suggesting factors other than physical barriers to be major determinants of population differentiation.

Local environmental conditions can determine the survival of a particular species and, therefore, limit its distribution (Brandon, 1990; Eriksson, 1998). Overwintering conditions for pollen beetles probably depend on factors such as soil structure, tillage practices, and climate, all of which are local conditions that may strongly influence winter mortality. Crop rotation practices and longer seasons for cultivation of Brassica in Southern Europe may also result in differences in selection pressures. A mix of winter and spring sown varieties of oilseed rape is more common in Sweden and Denmark than any of the other countries sampled. Differences in insecticide formulations and application frequency among farmers and regions are major selection mechanisms that would influence differentiation among populations but such factors are more difficult to study at a larger scale. In a study at a large geographic scale, both European and North American populations of another pest insect, Colorado potato beetle (Leptinotarsa decemlineata), showed a high level of population structure and low gene flow (Grapputo et al., 2005). It was suggested that pest insects may be able to establish large local populations that can maintain genetic variation for local adaptation.

TABLE 2. AMOVA of European pollen beetle populations. Fixation Indices: $F_{S C}=0.41, F_{S T}=0.45, F_{C T}=0.06$. Based on results of dendrogram of European beetles (Fig. 1).

\begin{tabular}{lccccc}
\hline Source of variation & d.f. & Sum of squares & $\begin{array}{c}\text { Variance compo- } \\
\text { nents }\end{array}$ & $\begin{array}{c}\text { Percentage of variation } \\
P \text {-values }\end{array}$ \\
\hline Among countries & 5 & 726.62 & $1.77 \mathrm{Va}$ & 6.34 & $<0.001$ \\
Among populations within countries & 8 & 905.99 & $10.74 \mathrm{Vb}$ & 38.51 & $<0.001$ \\
Within populations & 112 & 1722.96 & $15.38 \mathrm{Vc}$ & 55.14 & $<0.001$ \\
\hline Total & 125 & 3355.56 & 27.90 & & \\
\hline
\end{tabular}


TABLE 3. Population pairwise determinations of $F_{S T}$ values of European pollen beetle populations. Probability values are based on 10,000 permutations. Significance levels are $P<0.000001$ for the whole data set.

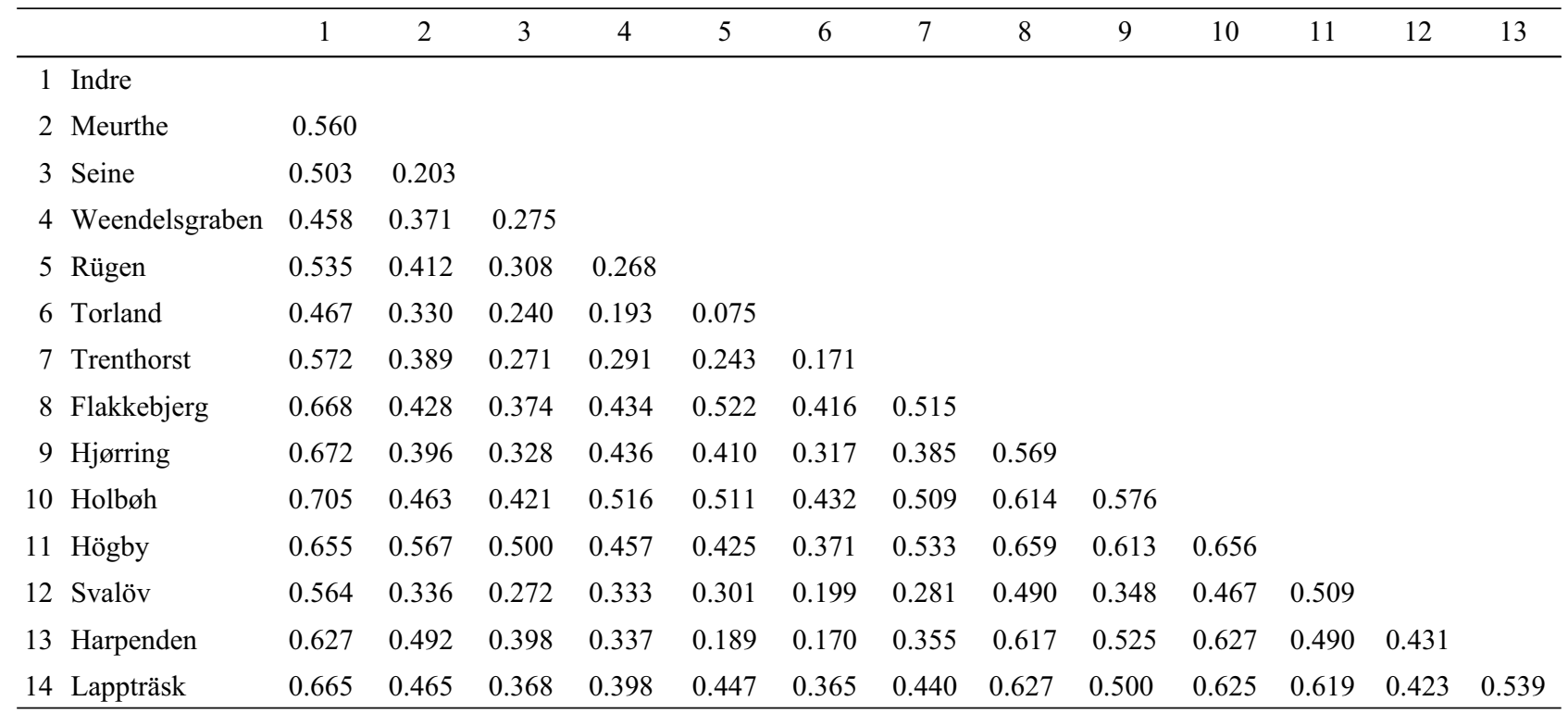

The possibility of a recent common founder effect among different populations of pollen beetles can not be excluded. In two studies of another important Brassica pest, the moth Plutella xylostella, there was no relationship between genetic and geographical distances at large geographical scales (Endersby et al., 2006; Pichon et al., 2006). One interpretation was that insects can be spread with plant material or that a recent rapid expansion of Brassica cultivation with small numbers founding local populations. $P$. xylostella is also known to disperse widely, moving with the help of strong winds operating at high altitudes. The possibility that pollen beetles were disseminated with plant material or even soil is not negligible. Although little is known about pollen beetle dispersal capability it is recorded that pollen beetles can move $10 \mathrm{~km}$ in 2 days (Tamir et al., 1967). Wind dispersal is certainly a factor to consider and certain wind directions prevail during different seasons of the year. It is not unlikely that some pollen beetles may move long distances when meteorological conditions are favourable, as suggested for the Colorado potato beetle (Wiktelius, 1981; Grapputo et al., 2005).

Further knowledge of population structure and gene flow between European pollen beetle populations as well as knowledge of resistance mechanisms should facilitate the development of strategies to manage insecticide resistance at local and regional scales. Local selection pressures may be important and it is, therefore, important to minimize selection pressure to keep susceptible insects alive. Short term options are the rotation of insecticides with different modes of action and stringent use of control thresholds and appropriate insecticide doses. Monitoring based on AFLP and selected fragments as markers (Behura, 2006) could be used to determine the effects on insect population structure, reflecting, e.g. local adaptation and fitness effects.
ACKNOWLEDGEMENTS. We thank B. Ulber, Y. Ballanger, L.M. Hansen, R. Piper, G.-B. Husberg, W. Büchs, C. Theis, and I. Williams for providing the pollen beetle material. A. Lundhagen and three reviewers provided helpful comments on the manuscript. This study was supported by grants from Stiftelsen Lantbruksforskning, the project "Molecular Ecology" financed by the Faculty of Natural Resources and Agricultural Sciences at SLU, H. Ax:son-Johnsons Stiftelse and N.-E. Stiftelsen.

\section{REFERENCES}

Balasaravanan T., Pius P.K., Kumar R.R, Muraleedharan N. \& SHASANY A.K. 2003: Genetic diversity among south Indian tea germplasm (Camellia sinensis, C. assamica and C. assamica spp. lasiocalyx) using AFLP markers. Plant Sci. 165: $365-372$.

BeHURA S.K. 2006: Molecular marker systems in insects: current trends and future avenues. Mol. Ecol. 15: 3087-3113.

Bensch S. \& Åkesson M. 2005: Ten years of AFLP in ecology and evolution: why so few animals? Mol. Ecol. 14: 2899-2914.

Blanc M.P., Lugon-Noulin N., Panighini C., Pijnenburg H. \& Rossi L. 2006: Structure of worldwide populations of Lasioderma seerricorne as revealed by amplified fragment length polymorphism profiles. Bull. Entomol. Res. 96: 111-116.

BONNEMAISON L. 1964: Insect pests of crucifers and their control. Annu. Rev. Entomol. 10: 233-256.

Brandon R. 1990: Adaptation and Environment. Princeton Univ. Press, Princeton, NJ, 214 pp.

Campbell D., Duchesne P. \& Bernatches L. 2003: AFLP utility for population assignment studies: analytical investigation and empirical comparison with microsatellites. Mol. Ecol. 12: 1979-1991.

Comins H.N. 1977: The development of insecticide resistance in the presence of migration. J. Theor. Biol. 64: 177-197.

Derron J.O., LeClech E., Bezençon N. \& Goy G. 2004: Résistance des méligèthes du colza aux pyréthrinoïdes dans le basin lémanique. Rev. Suisse Agric. 36: 237-242.

Détourné D., Delorme R. \& Ballanger Y. 2002: Résistance des méligèthes du colza: bilan de trois années d'enquête. AFPP - Sixième Conférence Internationale sur les Ravageurs 
en Agriculture 4-6 Décembre 2002, Montpellier. AFPP, Paris.

Efron B., Halloran E. \& Holmes S. 1996: Bootstrap confidence levels for phylogenetic trees. Proc. Nat. Acad. Sci. USA 93: $13429-13434$

Еквом B. 1995: Insect pests. In Kimber D.S. \& McGregor D.I. (eds): Brassica Oilseeds: Production and Utilization. CAB International, Wallingford, Oxon, pp. 141-152.

Еквом B. \& Borg A. 1996: Pollen beetle (Meligethes aeneus) oviposition and feeding preferences on different host plant species. Entomol. Exp. Appl. 78: 291-299.

Еквом В. \& Kuusk A.-K. 2001: Pollen beetles (Meligethes aeneus) and resistance against pyrethroids. Växtskyddsnotiser 65: 39-42 [in Swedish, English abstr.].

Endersby N.M., Mckechnie S.W., Ridland P.M. \& Weeks A.R. 2006: Microsatellites reveal a lack of structure in Australian populations of the diamondback moth, Plutella xylostella. Mol. Ecol. 15: 107-118.

ERIKSSON G. 1998: Evolutionary forces influencing variation among populations of Pinus sylvestris. Silva Fenn. 32: $173-184$.

Felsenstein J. 1989: PHYLIP - Phylogeny inference package (version 3.2). Cladistics 5: 164-166.

fFrench-Constant R.H., Daborn P.J. \& Le Goff G. 2004: The genetics and genomics of insecticide resistance. Trends Genet. 20: 163-170.

Giamoustaris A. \& Mithen R. 1996: The effect of flower colour and glucosinolates on the interaction between oilseed rape and pollen beetles. Entomol. Exp. Appl. 80: 206-208.

Grapputo A., Boman S., Lindström L., Lyytinen A. \& Mappes J. 2005: The voyage of an invasive species across continents: Genetic diversity of North American and European Colorado potato beetle populations. Mol. Ecol. 14: 4207-4219.

HANSEN L.M. 2003: Insecticide-resistant pollen beetles (Meligethes aeneus F) found in Danish oilseed rape (Brassica napus L) fields. Pest Manag. Sci. 59: 1057-1059.

Heimbach U., Muller A. \& Thieme T. 2006: First steps to analyse pyrethroid resistance of different oil seed rape pests in Germany. Nachrbl. Dt. Pflschutzdienst. 58: 1-5.

Hopkins R., Еквом B. \& Henkow L. 1998: Glucosinolate content and susceptibility for insect attack of three genotypes of Sinapis alba. J. Chem. Ecol. 24: 1203-1216.

Kazachkova N., Fahleson J. \& MeiJer J. 2004: Establishment of the Amplified Fragment Length Polymorphism (AFLP) technique for genotyping of pollen beetle (Meligethes aeneus) - a noxious insect pest on oilseed rape (Brassica napus). Mol. Biol. Reports 31: 37-42.

Kazachkova N., Meijer J. \& Еквом B. 2007: Genetic diversity in pollen beetles (Meligethes aeneus) in Sweden: role of spatial, temporal and insecticide resistance factors. Agr. Forest Entomol. 9: 259-269.

LABAte J.A. 2000: Software for population genetic analyses of molecular marker data. Crop Sci. 40: 1521-1528.

LabBe P., Lenormand T. \& Raymond M. 2005: On the worldwide spread of an insecticide resistance gene: a role for local selection. J. Evol. Biol. 18: 1471-1484.

LENORMAND T. \& RAYMOND M. 1998: Resistance management: the stable zone strategy. Proc. R. Soc. Lond. (B) 265: 1985-1990.

Lowe A., Harris S. \& Ashton P. 2004: Ecological Genetics: Design, Analysis, and Application. Blackwell, Oxford, UK, $326 \mathrm{pp}$.

Mariette S., Le Corre V., Austerlitz F. \& Kremer A. 2002 Sampling within the genome for measuring within-population diversity: trade-offs between markers. Mol. Ecol. 11: $1145-1156$.

NAHRUng H.F. \& Allen G.R. 2003: Geographical variation, population structure and gene flow between populations of Chrysophtharta agricola (Coleoptera: Chrysomelidae), a pest of Australian eucalypt plantations. Bull. Entomol. Res. 93: 137-144.

NEI M. 1978: Estimation of average heterozygosity and genetic distance from a small number of individuals. Genetics 89: 583-590.

Ner M. \& Li W.H. 1979: Mathematical model for studying genetic variation in terms of restriction endonucleases. Proc. Nat. Acad. Sci. USA 76: 5269-5273.

NiLsson C. 2003: Parasitoids of pollen beetles. In Alford D.V. (ed.): Biocontrol of Oilseed Rape. Blackwell, Oxford, UK, pp. 73-86.

Paetkau D., Calvert W., Sterling I. \& Strobeck C. 1995: Microsatellite analysis of population structure in Canadian polar bears. Mol. Ecol. 4: 347-354.

Peakall R. \& Smouse P.E. 2006: GenAlEx6: genetic analysis in Excel. Population genetic software for teaching and research. Mol. Ecol. Notes 6: 288-295.

Pichon A., Arvanitakis L., Roux O., Kirk A.A., Alauzet C., Bordat D. \& Legal L. 2006: Genetic differentiation among various populations of the diamondback moth Plutella xylostella. Bull. Entomol. Res. 96: 137-144.

Quinn G. \& Keough M. 2002: Experimental Design and Data Analysis for Biologists. Cambridge University Press, Cambridge, $537 \mathrm{pp}$.

Rask L., Andréasson E., Ekbom B., Eriksson S., Pontoppidan B. \& Meijer J. 2000: Myrosinase: Gene family evolution and herbivore defense in Brassicaceae. Plant Mol. Biol. 42: 93-113.

Reineke A., Karlovsky P. \& Zebitz C.P.W. 1999: Amplified fragment length polymorphism analysis of different geographic populations of the gypsy moth, Lymantria dispar. Bull. Entomol. Res. 89: 79-88.

RoHLF F.J. 1973: Algorithm 76. Hierarchical clustering using the minimum spanning tree. Computer J. 16: 93-95.

Roush R.T. \& DALY J.C. 1990: The role of population genetics in resistance research and management. In Roush R.T. \& Tabashnik B.E. (eds): Pesticide Resistance in Arthropods. Chapman \& Hall, New York, pp. 97-152.

SaItou N. \& NeI M. 1987: The neighbor-joining method: a new method for reconstructing phylogenetic trees. Mol. Biol. Evol. 4: 406-425.

Salvato P., Battisti A., Concato S., Masutti L., Patarnello T. \& ZANE L. 2002: Genetic differentiation in the winter pine processionary moth (Thaumetopoea pityocampa - wilkinsoni complex), inferred by AFLP and mitochondrial DNA markers. Mol. Ecol. 11: 2435-2444.

Schneider S., Roessli D. \& Excoffier L. 2000: Arlequin ver. 2000: A Software for Population Genetics Analysis. Genetics and Biometry Laboratory, Univ. of Geneva, Switzerland.

Tamir L., Šedivý J., Bergmannová E. \& Hanker I. 1967: Further experience obtained in studies on dispersal flight of Meligethes aeneus F., marked with $\mathrm{P}^{32}$. Acta Entomol. Bohemoslov. 64: 325-332.

Van de Peer Y. \& De Wachter R. 1997: Construction of evolutionary distance trees with TREECON for Windows: accounting for variation in nucleotide substitution rate among sites. Comp. Applic. Biosci. 13: 227-230.

Vekemans X., Beaumens T., Lemaire M. \& Roldan-Ruiz I. 2002: Data from amplified fragment length polymorphism (AFLP) markers show indication of size homoplasy and of a 
relationship between degree of homoplasy and fragment size. Mol. Ecol. 11: 139-151.

Vos P.R., Hogers M., Bleeker M., Reijans M., Van De Lee T., Hornes M., Frijters A., Pot J., Peleman J. \& Kuiper M. 1995: AFLP: a new technique for DNA fingerprinting. Nucl. Acids Res. 23: 4407-4414.

Wiktelius S. 1981: Wind dispersal of insects. Grana 20: 205-207.
Williams I.H., Frearson D., Barari H. \& McCartney A. 2007: Migration to and dispersal from oilseed rape by the pollen beetle, Meligethes aeneus, in relation to wind direction. Agric. Forest Entomol. 9: 279-286.

You F.M., Luo M.C., Gu Y.Q., Lazo G.R., Deal K., DvoraK J. \& ANDERson O.D. 2007: GenoProfiler: Batch processing of high throughput capillary fingerprinting data. Bioinformatics 23: $240-242$.

Received January 9, 2008; revised and accepted September 24, 2008 